EXTENDED REPORT

\title{
Effect of tumour necrosis factor $\alpha$ antagonists on serum transaminases and viraemia in patients with rheumatoid arthritis and chronic hepatitis $C$ infection
}

\author{
J R Peterson, F C Hsu, P A Simkin, M H Wener
}

Ann Rheum Dis 2003;62:1078-1082

See end of article for authors' affiliations

.......

Correspondence to: Dr M H Wener Department of Laboratory Medicine, Box 357110 ,

UWMC, Seattle, WA 98195, USA:

wener@u.washington.edu

Accepted 5 March 2003
Background: Tumour necrosis factor $\alpha$ (TNF $\alpha$ ) antagonists are effective for the treatment of rheumatoid arthritis (RA), but concerns remain about the safety of these agents in the presence of chronic infections, including hepatitis $\mathrm{C}$ virus (HCV) infection.

Objective: To examine the influence of treatment with TNF $\alpha$ antagonists on levels of HCV viraemia and serum transaminases in patients with RA and HCV.

Methods: In a retrospective survey the course of $16 \mathrm{HCV}$ infected patients with RA who had received the TNF $\alpha$ antagonists etanercept or infliximab was analysed. Eight additional patients with RA and HCV were also enrolled into a three month prospective trial of etanercept. Serum concentrations of albumin, alkaline phosphatase, aspartate aminotransferase, alanine aminotransferase, and HCV were followed.

Results: Viraemia was measured in 22 patients receiving a TNF $\alpha$ antagonist at the start of treatment and after 1-34 months (median 9 months follow up). Twenty four patients had serial tests of liver related enzymes and albumin. None of the differences between liver related tests at baseline and at follow up achieved significance $(p>0.05)$. Similarly, the mean HCV measurement at $1-3,4-6,7-12$, and $13-$ 34 months did not differ significantly from baseline ( $p>0.05)$.

Conclusion: In this study, liver related blood tests and HCV viral load measurements did not change substantially. These findings suggest that TNF $\alpha$ antagonists merit further study for the treatment of RA in $\mathrm{HCV}$ infected patients. Larger and longer term studies are still needed.

\section{PATIENTS AND METHODS}

Retrospective study

A search was conducted through our university medical centre database to identify patients with both RA and HCV. Additionally, rheumatologists in Washington State were asked to complete a data form for any HCV infected patients

with RA in their practice who were treated with TNF $\alpha$ antagonists. Values for HCV viral load and serum liver related tests (LRTs: aspartate aminotransferase (AST), alanine aminotransferase (ALT), alkaline phosphatase, and albumin) were recorded for patients before TNF $\alpha$ blockade, and at various times after the start of treatment. Patient age, sex, alcohol consumption, current disease modifying antirheumatic drug (DMARD) treatment, non-steroidal anti-inflammatory drug (NSAID) use, $x$ ray confirmation of erosive disease, and method of HCV measurement were recorded. Viral loads were measured by either polymerase chain reaction (PCR) or branch chain assays, with the same method consistently used in all but one case. In that single case, the more sensitive PCR method found no detectable viral equivalents on two occasions, whereas the less sensitive branch chain method quantified viral particle equivalents at another time point. Three different laboratories measured viral loads, with 18/22 cases analysed at the University of Washington Department of Laboratory Medicine. During the study, the units for reporting HCV viral loads changed from "equivalents/ml" to "IU/ml". A multiplication factor of 6.3 was applied to IU numbers to convert to "equivalents/ml" and all values were then converted to $\log 10$ for analysis. Because six different laboratories contributed LRT data, we

\footnotetext{
Abbreviations: ACR, American College of Rheumatology; ALT, alanine aminotransferase; $A S T$, aspartate aminotransferase; CRP, $C$ reactive protein; DMARD, disease modifying antirheumatic drug; ESR, erythrocyte sedimentation rate; $H A Q$, Health Assessment Questionnaire; HCV, hepatitis C virus; LRT, liver related test; MTX, methotrexate; NSAID, non-steroidal anti-inflammatory drug; PCR, polymerase chain reaction; $\mathrm{PT}$, prothrombin time; PT, partial thromboplastin time; RA, rheumatoid arthritis; TNF $\alpha$, tumour necrosis factor $\alpha$
} 
chose to convert the data to a percentage of the upper limit of normal for each test in each laboratory to provide comparable values. All viral load testing was done on fresh specimens, without prolonged storage.

\section{Prospective study}

Patients with active RA and concurrent HCV who had never received TNF $\alpha$ antagonists were invited to participate in a four month prospective study. Eligible patients were at least 18 years of age and had chronic stable HCV infection (defined as the absence of clinical evidence of decompensated liver disease, and/or a liver biopsy showing no cirrhosis) and normal albumin, normal prothrombin time (PT) and partial thromboplastin time (PTT). All patients met the American College of Rheumatology (ACR) criteria for $\mathrm{RA}^{7}$ were in functional class I, II, or III, ${ }^{8}$ and had been receiving their current antirheumatic drugs for three months or more. Concomitant treatment with stable doses of oral corticosteroids and/or NSAIDs was permitted, but corticosteroid doses could not exceed the equivalent of $10 \mathrm{mg}$ of prednisone a day, and NSAID doses could not exceed the maximum recommended dose. Intra-articular corticosteroids were not permitted during the study or for four weeks before enrolment. Patients taking interferon alfa and/or ribavirin within the prior six months were not accepted. No patient was enrolled who was HIV positive, had current bacterial infection, was pregnant, or had alcohol consumption greater than $90 \mathrm{ml}$ (3 ounces) a day over the previous six months.

At enrolment, patients had complete blood count, serum albumin, AST, ALT, gamma glutamyl transpeptidase, rheumatoid factor, erythrocyte sedimentation rate (ESR), C reactive protein (CRP), PT, PTT, and quantitative HCV by branch chain signal amplification test (Chiron). If the HCV branch chain assay was negative, a more sensitive, quantitative PCR assay was used to quantify viral load. These laboratory tests were repeated 2-4 weeks later, as a second baseline data point, before starting etanercept. All viral load testing was done on fresh specimens, without prolonged storage. The etanercept dosage was $25 \mathrm{mg}$ given twice weekly by subcutaneous injection. Patients returned at monthly intervals for four months. At the week 12 visit, the patients were asked to stop etanercept until the week 16 visit when they restarted if the patient and doctor agreed it had been beneficial. A standard Health Assessment Questionnaire (HAQ), doctor and patient global disease activity visual analogue scale, the before-mentioned blood tests, and tender and swollen joint counts were performed at each visit. ACR criteria for response to treatment of RA were used to assess efficacy. ${ }^{9}$

HCV viral loads were expressed as $\log 10$ of viral equivalents $/ \mathrm{ml}$. Average values are expressed as arithmetic means (SD). Comparisons of differences between mean values were performed by paired $t$ tests using Microsoft Excel (Redmond, WA). Not all patients were tested at all time points or ranges, therefore data from a particular time range were compared only with the baseline data from those same patients. Power calculations were performed using a statistical power software package (PS, Dupont WD, Plummer WD, Vanderbilt University, 1997, version 1.0.15, http:// www.mc.vanderbilt.edu/prevmed/ps), and a sample size of seven was calculated to detect clinically significant differences in mean transaminases and mean viral loads with a power of $80 \%$, using paired $t$ tests. Statistical calculations were performed with Excel (Microsoft, Redmond, WA). Differences were interpreted as significant at $\mathrm{p}<0.05$, without adjustment for multiple comparisons. For comparisons of changes in liver tests and viral loads over time, paired two tailed $t$ tests were performed comparing each patient with their own baseline result. Changes in HCV viral loads were converted to log values before statistical analyses.

Informed consent to participate in this study was obtained for all prospective patients. Both retrospective and prospective portions of the study were reviewed and approved by our institutional review board (Human Subjects Committee) before any data collection.

\section{RESULTS}

Data were available for 24 cases (16 retrospective, 8 prospective; 21 etanercept, 3 infliximab) using TNF $\alpha$ antagonists for at least two months. The patients in the study (13 men, 11 women) had a mean age of 50 (range of 38-60). Most of the patients had longstanding disease, with over five years since the diagnosis of RA for 16 patients, and over five years from the time of diagnosis of HCV for 13. No patient had either RA or HCV diagnosed within one year before the study, and the diagnoses had been established between one and two years before the study for only one patient with RA and two patients with HCV. Seventeen patients used NSAIDs. Of the patients studied retrospectively, 10 were receiving multiple DMARDs and four were taking methotrexate (MTX), including one of those using MTX in combination with hydroxychloroquine. No patient drank alcohol in excess of $90 \mathrm{ml}$ ( 3 ounces) a day and 15 did not drink alcohol. All but one patient had erosions on plain radiographs.

Twenty two patients had at least one baseline viral load measured before starting $\mathrm{TNF} \alpha$ antagonist treatment, and additional viral measurements were available at $1-34$ months during TNF $\alpha$ antagonist treatment. The median follow up was nine months. HCV measurement was not performed at consistent times in the retrospective study. There were no significant differences between the mean viral loads at baseline and at 1-3, 4-6, 7-12, or 12-34 months (table 1). Sixteen subjects showed a decrease in the viral load from the first to the last measurement available, whereas the load increased in $6 / 22(p=0.052$ by binomial distribution). Among all patients, the mean ratio of the log of the viral load at the end of treatment compared with the baseline log value was $0.98(0.10)$.

Among the eight patients enrolled in the prospective study, the viral load decreased in seven while taking etanercept. Between the baseline studies and the end of the three months taking the drug, the log viral load fell from an average of 6.779 (0.595) (median 6.819) to 6.500 (0.395) (median 6.459), a difference that was not significant. Two patients with substantial clinical improvement in RA while taking etanercept asked to be removed from the formal study after three months in order to continue taking the drug without the planned withdrawal period. Another was lost to follow up after three months. For the remaining five patients, the mean log of the HCV viral load did not change significantly between the third month (with etanercept, mean of log viral load $6.65(0.28))$ and the fourth month

Table $1 \mathrm{HCV}$ measurement in patients while receiving TNF $\alpha$ antagonists

\begin{tabular}{ll}
\hline Time & Mean (SD) log viral load \\
\hline Baseline $(n=22)$ & $6.476(0.726)$ \\
$1-3$ Months $(n=19)$ & $6.032(1.613)$ \\
$4-6$ Months $(n=4)$ & $5.945(0.477)$ \\
$7-12$ Months $(n=8)$ & $6.041(0.551)$ \\
$13-34$ Months $(n=8)$ & $5.402(2.098)$ \\
\hline
\end{tabular}

Mean (SD) of the log of the viral load, in virus particle equivalents $/ \mathrm{ml}$. $\mathrm{n}=$ number of cases with data available at the selected time. 

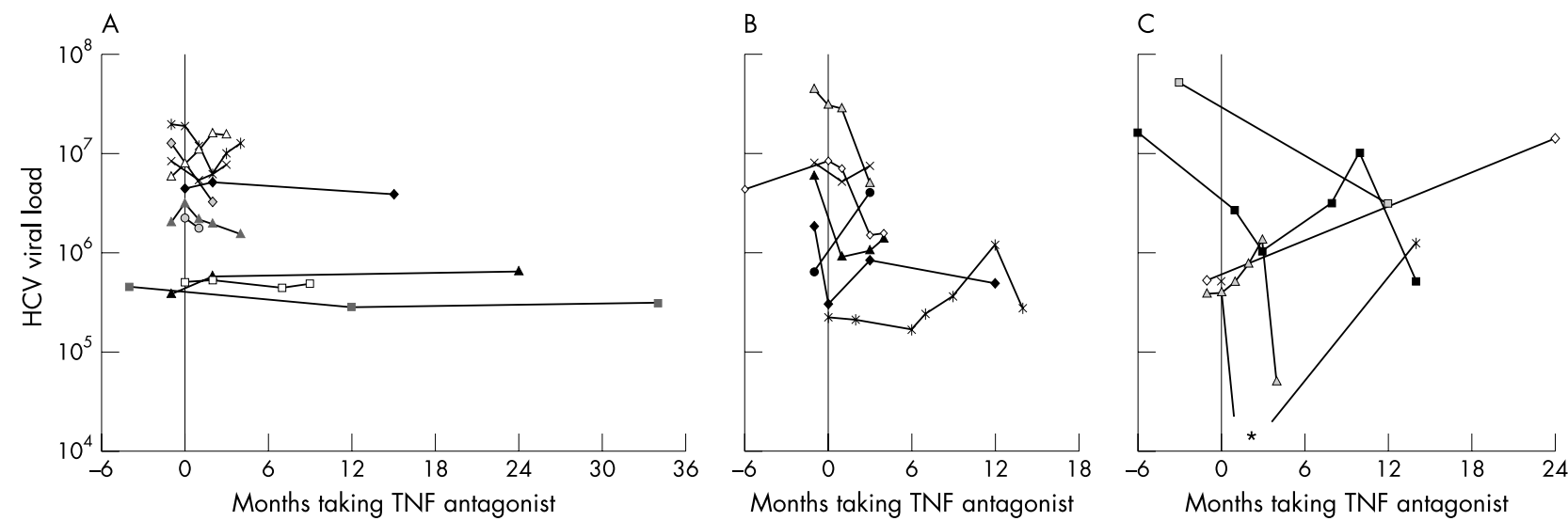

Figure 1 Measurement of plasma viraemia before and after starting TNF $\alpha$ antagonists. A TNF $\alpha$ antagonist was started at time $=0$. Data from cases with (A) <5-fold; (B) 5-10-fold; (C) >10-fold change between maximum and minimum level of plasma viraemia. For one case, plasma viraemia was present at the beginning of the study and at the end of follow up, but undetectable (signified by the asterisk *) at one and three months after starting etanercept. Overall, no significant change was seen in the average levels of viraemia while taking TNF $\alpha$ antagonists.

(measured after four weeks without the drug, mean log 6.29 (0.96), $\mathrm{p}=0.14)$.

Of the 22 patients with repeated HCV measurement, 10 (45\%) had a one- to fivefold difference between the maximum and minimum values, $7(32 \%)$ had a five- to 10 fold change, and $5(23 \%)$ had $>10$-fold change (fig 1 ). This distribution was significantly different $\left(p<0.005\right.$ by $\chi^{2}$ test $)$ from the corresponding values of $71 \%, 22 \%$, and $7 \%$, respectively, for $1-5$ fold, 5-10 fold, and >10-fold spontaneous fluctuation in viral loads observed by Arase et al. ${ }^{6}$ Of the seven cases with 5-10-fold changes in viral load, the maximum value was observed while taking a TNF $\alpha$ antagonist in two cases, and while not taking the drug in five cases. Among the five cases with a $>10$ fold difference between the maximum and minimum values, the maximum value was seen while not taking a TNF $\alpha$ antagonist in two cases and while taking the drug in three cases. (In one of the latter cases, both the maximum and the minimum values were seen while taking etanercept.)

Serum tests in the 24 cases showed no significant changes in albumin, alkaline phosphatase, AST, or ALT between baseline and 1-3, 4-6, 7-12, and 13-34 month observation periods $(\mathrm{p}=0.18-1.0)$ (table 2 ). No subject was considered to have a clinically significant change in LRT, and none of the values increased more than twofold (preset as a criterion of potential toxicity for safety monitoring in the prospective trial). The serum albumin showed no trends over the course of the study, but for one case hypoalbuminaemia at baseline (albumin $=27 \mathrm{~g} / \mathrm{l}$ ) increased to $32 \mathrm{~g} / \mathrm{l}$ after taking etanercept for three months.

Table 2 Liver enzyme tests in patients receiving TNF $\alpha$ antagonists

\begin{tabular}{llcc}
\hline Time & AP & AST & ALT \\
\hline Baseline $(n=24)$ & $86(72)[65]$ & $121(110)[69]$ & $122(96)[78]$ \\
$1-3$ Months $(n=22)$ & $69(35)[58]$ & $105(71)[80]$ & $129(99)[94]$ \\
$4-6$ Months $(n=9)$ & $97(47)[59]$ & $70(69)[77]$ & $77(79)[80]$ \\
$7-12$ Months $(n=9)$ & $76(45)[63]$ & $93(56)[78]$ & $106(100)[82]$ \\
$13-34$ Months & $79(47)[69]$ & $100(109)[70]$ & $99(100)[77]$ \\
$(n=12)$ & & & \\
\hline
\end{tabular}

Mean (SD) [median]. Expressed as the percentage of the upper limit of normal for each test in the laboratory used for measurement. $n=$ number of cases with data available at the selected time.

AP, alkaline phosphatase; AST, aspartate aminotransferase; ALT, alanine aminotransferase.
The primary purpose of this study was to seek evidence of worsening hepatitis or increased viraemia, or both, when patients were receiving $\mathrm{TNF} \alpha$ antagonists, but assessment of efficacy was also performed in the prospective study. Improvements were consistent with previous studies of the efficacy of etanercept in patients with RA without HCV infection. ACR20 was achieved in seven of eight patients, ACR50 in five, and ACR70 in three. The mean HAQ score decreased from 13.8 at baseline to 6.5 at three months $(p<0.01)$. The mean patient global assessment decreased from 51.5 to $31.6(\mathrm{p}<0.05)$, and the mean doctor's global assessment decreased from 55.5 to $27.3(\mathrm{p}<0.01)$. The mean joint count decreased from 21.2 to $10.3((\mathrm{p}<0.01)$ at three months.

The ESR was recorded at baseline and at the end of the data collection period for 13 cases, including all patients studied prospectively and five retrospectively, and fell from 25.2 to $18.2 \mathrm{~mm} / \mathrm{lst} \mathrm{h}(\mathrm{p}<0.05)$. Baseline and end point measurements of CRP were also available for 13 cases, and fell from $8.6 \mathrm{mg} / \mathrm{l}$ to $4.8 \mathrm{mg} / \mathrm{l}$, a decrease that did not reach significance $(\mathrm{p}=0.07)$.

\section{DISCUSSION}

Treatment of patients with coexisting RA and HCV poses a difficult therapeutic challenge because of the risk that the treatment of RA will aggravate hepatitis and increase viraemia. Many DMARDs, including MTX and leflunomide, have the potential for hepatotoxicity, and drugs that are less hepatotoxic may not be adequate to control severe rheumatoid disease. ${ }^{3}$ Corticosteroids are a worrisome alternative because high dose methylprednisolone has been shown to increase the HCV viral load up to 100 -fold ${ }^{10}$ and lower doses may cause a more modest increase in levels of HCV viraemia. ${ }^{11-13}$

Aggressive immunosuppression, as seen after organ transplantation, frequently leads to high levels of HCV viraemia in association with exacerbation of hepatitis and a rapidly progressive form of HCV infection. ${ }^{14}{ }^{15}$ Higher HCV viral loads have been seen in association with worsening liver histopathology, ${ }^{10}{ }^{16}$ including rapid progression to cirrhosis and end stage liver disease. ${ }^{17}{ }^{18}$ Patients coinfected with HIV and HCV are another group in which immunosuppression is associated with accelerated progression of liver damage and worse prognosis. ${ }^{19}$

TNF $\alpha$ antagonists are effective in the treatment of RA and have no known direct liver toxicity. Although there are concerns about their potential for exacerbation of infec- 
tions, ${ }^{2021}$ including reactivation of tuberculosis, ${ }^{22}$ the effect of TNF $\alpha$ antagonists on the course of HCV infection is not established. We are aware of two case reports in which infliximab was used in patients with HCV infection and Crohn's disease, and in those cases infliximab treatment was not associated with progression of HCV viraemia or worsening hepatitis. ${ }^{23}{ }^{24}$ In our series of 24 patients, liver function tests and HCV viral load did not worsen over the median of nine months (range 2-34) that patients were followed up. This lack of change in viral load and transaminases is in contrast with the changes commonly seen in heavily immunosuppressed HCV patients after organ transplantation, a finding that suggests that TNF $\alpha$ antagonists, when used at recommended doses, do not accelerate HCV infection. Because of the small number of cases, our data do not allow us to examine the influence of infliximab and etanercept separately.

Liver biopsy is considered the standard for assessing changes in activity of HCV hepatitis. Baseline liver biopsy specimens were obtained in some of our patients, but serial biopsies were not performed because of potential morbidity, expense, and insensitivity to change over the short term. We acknowledge the lack of serial liver biopsy information as a limitation of our study. Nevertheless, serum concentrations of transaminases and other LRTs provide substantial indirect information about the condition of the liver in HCV infection, particularly in response to immunosuppression. Serum transaminases and levels of viraemia rise rapidly as hepatitis recurs in immunosuppressed patients after organ transplantation. ${ }^{10}{ }^{26-28}$ Consistently normal levels of transaminases, as seen in the large majority of our patients, are associated with less progression of liver disease either with or without immunosuppression..$^{29}$ Conversely, raised or rising transaminases are associated with increased pathological changes in liver histology. ${ }^{30-33}$ Furthermore, liver biopsies themselves can have substantial problems with interpretation and lack of homogeneity, including varied histology and viral loads at different sites within the same liver. ${ }^{25}$

Although there were no significant changes in mean viral load, substantial variation occurred in a few subjects. Such changes may, in part, reflect analytical variation in viral measurement, estimated at $0.31 \log$ (twofold) change using the branch chain DNA assay, ${ }^{17}$ and spontaneous biological fluctuation. Arase et al followed monthly HCV viral loads over a two year period in 212 patients and found that $71 \%$ had nearly constant viral titres (variation between one- and fivefold), $22 \%$ had slight fluctuation (between five and 10 fold), and $7 \%$ had large fluctuation (>10-fold). ${ }^{6}$ A significantly greater proportion of our cases had larger fluctuations, with $32 \%$ having a $5-10$ fold change, and $23 \%$ demonstrating a $>10$-fold change in levels of plasma viraemia. In three of the five cases with a $>10$-fold change in viraemia, the lowest level occurred while the patient was taking TNF $\alpha$ antagonists. In neither of the two cases with a large increase in viral loads was there a corresponding increase in LRTs associated with the increased viraemia, and the doctors caring for those patients did not discontinue the TNF $\alpha$ antagonists. The increases seen in those two cases might be due to chance alone, as observed in the studies of Arase et al or might reflect susceptibility for exacerbation of HCV viraemia caused by $\mathrm{TNF} \alpha$ antagonism in those particular cases. The lack of significant overall increase in mean viral load during $\mathrm{TNF} \alpha$ blockade suggests that TNF $\alpha$ is not critical for suppressing HCV infection in most cases. Nevertheless, the potential for increase in HCV RNA levels in a minority of cases leads us to recommend monitoring HCV quantitative viraemia in patients receiving TNF $\alpha$ antagonists, and to consider discontinuing TNF $\alpha$ antagonists in selected cases with substantially rising levels of viraemia.
The role of $\mathrm{TNF} \alpha$ and $\mathrm{TNF} \alpha$ antagonists in modulating infections remains unclear. ${ }^{34}$ Infliximab is associated with increased risk of exacerbations of mycobacterial infections. ${ }^{22}$ This finding may be explained by experimental observations indicating that granuloma formation and intracellular killing of mycobacteria depends on TNF $\alpha .{ }^{35}{ }^{36} \mathrm{TNF} \alpha$ antagonists used to treat bacterial sepsis do not improve mortality of the sepsis syndrome, and one large study reported a dose dependent increase in mortality associated with $\mathrm{TNF} \alpha$ antagonists, ${ }^{37}$ suggesting that $\mathrm{TNF} \alpha$ antagonists may exacerbate at least some bacterial infections. The role of TNF $\alpha$ in viral infections is also complex and divergent. In experimental animals, TNF $\alpha$ may either retard or promote viral infections, depending on the particular experimental model and virus. ${ }^{38} \mathrm{HCV}$ may enhance TNF induced hepatic cell necrosis, thereby contributing to liver damage. ${ }^{39}$ Clinical studies of TNF $\alpha$ antagonists in HIV infection have demonstrated no change in HIV quantitative viraemia. ${ }^{40}$ In an illustrative case report, a patient with HIV related psoriatic arthritis treated with etanercept showed no flare in HIV viraemia, but had severe bacterial infections, possibly due to etanercept. ${ }^{41}$ Thus, the data available suggest that chronic viral infections such as HIV and HCV may not be a contraindication to TNF $\alpha$ antagonist treatment, but there may be a risk of exacerbation of certain bacterial infections. Importantly, in our study TNF $\alpha$ blockade did not significantly change the mean LRT concentrations or viral loads in chronically HCV infected patients with RA. Long term and larger studies are needed to extend and confirm our results, but the short term data are reassuring and suggest that use of TNF $\alpha$ blockade in patients with RA with chronic, stable HCV infection merits further study.

\section{ACKNOWLEDGEMENTS}

We would like to thank all the rheumatologists and allied healthcare professionals who submitted data and patients for this study, Dr Anne Larson for her advice about HCV hepatitis, and Andrea Burns for her help in preparing this manuscript.

This study was supported by NIH training grant 5 T32 AR 07108-25. Supplemental funding for laboratory tests was provided by the University of Washington Department of Laboratory Medicine.

Jeff $\mathrm{R}$ Peterson, MD received a travel grant from Immunex Corporation, Seattle Washington, USA to present this work at the annual meeting of the European League Against Rheumatism (EULAR) 2002 in Stockholm, Sweden, 12-15 June 2002. These data were presented in preliminary form at EULAR and at the ACR annual meeting in San Francisco, 2001.

\section{Authors' affiliations}

J R Peterson, F C Hsu, P A Simkin, M H Wener, Division of Rheumatology, University of Washington, USA

M H Wener, Department of Laboratory Medicine, University of Washington, USA

\section{REFERENCES}

1 Baffoni L, Frisoni M, Miniero R, Righetti F, Sprovieri G, Ferri S. True positive anti-HCV tests in rheumatoid arthritis. Br J Rheumatol 1993:32:349-50.

2 Vaz Patto J, Piexe P, Parente M, Maderia H, Micaelo M, Teixeria A, Vilar A. Treating patients with rheumatoid arthritis and hepatitis $C$ : a major problem [abstract]. Arthritis Rheum 1996;39(suppl):S147.

3 Mok MY, Ng WL, Yuen MF, Wong RW, Lau CS. Safety of disease modifying antirheumatic agents in rheumatoid arthritis patients with chronic viral hepatitis. Clin Exp Rheumatol 2000;18:363-8.

4 Maillefert JF, Muller G, Bour JB, Dougados M, Tavernier C, Dijon MB. Prevalence of hepatitis $C$ virus infection in rheumatoid arthritis patients [abstract]. Arthritis Rheum 2001;44(suppl):S279.

5 Suzuki Y, Uehara R, Tajima C, Noguchi A, Ide M, Ichikawa Y, et al. Elevation of serum hepatic aminotransferases during treatment of rheumatoid arthritis with low-dose methotrexate. Risk factors and response to folic acid. Scand J Rheumatol 1999;28:273-81.

6 Arase Y, Ikeda K, Chayama K, Murashima N, Tsubota A, Suzuki Y, et al. Fluctuation patterns of HCV-RNA serum level in patients with chronic hepatitis C. J Gastroenterol 2000;35:221-5. 
7 Arnett FC, Edworthy SM, Bloch DA, McShane DJ, Fries JF, Cooper NS, et al. The American Rheumatism Association 1987 revised criteria for the classification of rheumatoid arthritis. Arthritis Rheum 1988;31:315-24.

8 Hochberg MC, Chang RW, Dwosh I, Lindsey S, Pincus T, Wolfe F. The American College of Rheumatology 1991 revised criteria for the classification of global functional status in rheumatoid arthritis. Arthritis Rheum 1992;35:498-502.

9 Felson DT, Anderson JJ, Boers M, Bombardier C, Furst D, Goldsmith C, et al. American College of Rheumatology. Preliminary definition of improvement in rheumatoid arthritis. Arthritis Rheum 1995:38:727-35.

10 Gane EJ, Naoumov NV, Qian KP, Mondelli MU, Maertens G, Portmann BC, et al. A longitudinal analysis of hepatitis $C$ virus replication following liver transplantation. Gastroenterology 1996;1 10:167-77.

11 Guilera M, Forns X, Torras X, Enriquez J, Coll S, Sola R, et al. Pre-treatment with prednisolone does not improve the efficacy of subsequent alpha interferon treatment in chronic hepatitis C. J Hepatol 2000;33:135-41.

12 Magrin S, Craxi A, Fabiano C, Simonetti RG, Fiorentino G, Marino L, et al. Hepatitis $C$ viraemia in chronic liver disease: relationship to interferon-alpha or corticosteroid treatment. Hepatology 1994;19:273-9.

13 Chayama K, Tsubota A, Kobayashi M, Hashimoto M, Miyano Y, Koike H, et al. A pilot study of corticosteroid priming for lymphoblastoid interferon alfa in patients with chronic hepatitis C. Hepatology 1996;23:953-7.

14 Berenguer M, Lopez-Labrador FX, Wright TL. Hepatitis C and liver transplantation. J Hepatol 2001;35:666-78.

15 McCaughan GW, Zekry A. Effects of immunosuppression and organ transplantation on the natural history and immunopathogenesis of hepatitis $C$ virus infection. Transpl Infect Dis 2000;2:166-85.

16 Aardema KL, Nakhleh RE, Terry LK, Burd EM, Ma CK, Moonka DK, et al. Tissue quantification of hepatitis $C$ virus RNA with morphologic correlation in the diagnosis of recurrent hepatitis $C$ virus in human liver transplants. Mod Pathol 1999; 12:1043-9.

17 Gretch DR. Diagnostic tests for hepatitis C. Hepatology 1997;26/suppl 1):43-7S.

18 Gretch DR, Bacchi CE, Corey L, dela Rosa C, Lesniewski RR, Kowdley K, et al. Persistent hepatitis $C$ virus infection after liver transplantation: clinical and virological features. Hepatology 1995;22:1-9.

19 Rodriguez-Rosado R, Perez-Olmeda M, Garcia-Samaniego J, Soriano V. Management of hepatitis C in HIV-infected persons. Antiviral Res 2001;52:189-98

20 Criscione LG, St Clair EW. Tumor necrosis factor-alpha antagonists for the treatment of rheumatic diseases. Curr Opin Rheumatol 2002;14:204-11.

21 Furst DE, Keystone E, Maini RN, Smolen JS. Recapitulation of the round-table discussion-assessing the role of anti-tumour necrosis factor treatment in the treatment of rheumatoid arthritis. Rheumatology (Oxford) 1999;38(suppl 2):50-3.

22 Keane J, Gershon S, Wise RP, Mirabile-Levens E, Kasznica J, Schwieterman WD, et al. Tuberculosis associated with infliximab, a tumor necrosis factor alpha-neutralizing agent. N Engl J Med 2001;345:1098-104.

23 Biancone L, Del Vecchio Blanco G, Pallone F, Castiglione F, Bresci G, Sturniolo G. Immunomodulatory drugs in Crohn's disease patients with hepatitis B or C virus infection. Gastroenterology 2002;122:593-4.

24 Campbell S, Ghosh S. Infliximab treatment for Crohn's disease in the presence of chronic hepatitis C infection. Eur J Gastroenterol Hepatol 2001;13:191-2.

25 Fanning L, Loane J, Kenny-Walsh E, Sheehan M, Whelton M, Kirwan W, et al. Tissue viral load variability in chronic hepatitis C. Am J Gastroenterol 2001:96:3384-9.
26 Duvoux C, Pawlotsky JM, Cherqui D, Tran van Nhieu J, Metreau JM, Fagniez PL, et al. Serial quantitative determination of hepatitis $C$ virus RNA levels after liver transplantation. A useful test for diagnosis of hepatitis $C$ virus reinfection. Transplantation 1995:60:457-61.

27 Fukumoto T, Berg T, Ku Y, Bechstein WO, Knoop M, Lemmens HP, et al. Viral dynamics of hepatitis $C$ early after orthotopic liver transplantation: evidence for rapid turnover of serum virions. Hepatology 1996;24:1351-4.

28 Gugenheim J, Baldini E, Mazza D, Fabiani P, St Paul MC, Goubaux B, et al. Recurrence of hepatitis $C$ virus after liver transplantation. Transpl Int 1994;7(suppl 1):S224-6.

29 Costes V, Durand L, Pageaux GP, Ducos J, Mondain AM, Picot MC, et al. Hepatitis $C$ virus genotypes and quantification of serum hepatitis C RNA in liver transplant recipients. Relationship with histologic outcome of recurrent hepatitis C. Am J Clin Pathol 1999;111:252-8.

30 Assy N, Minuk GY. Serum aspartate but not alanine aminotransferase levels help to predict the histological features of chronic hepatitis $C$ viral infections in adults. Am J Gastroenterol 2000;95:1545-50.

31 Cahen DL, van Leeuwen DJ, ten Kate FJ, Blok AP, Oosting J, Chamuleau RA. Do serum ALAT values reflect the inflammatory activity in the liver of patients with chronic viral hepatitis? Liver 1996;16:105-9.

32 Sheth SG, Flamm SL, Gordon FD, Chopra S. AST/ALT ratio predicts cirrhosis in patients with chronic hepatitis $C$ virus infection. Am J Gastroenterol 1998;93:44-8.

33 Shiffman ML, Hofmann CM, Thompson EB, Ferreira-Gonzalez A, Contos MJ, Koshy A, et al. Relationship between biochemical, virological, and histological response during interferon treatment of chronic hepatitis C. Hepatology 1997:26:780-5

34 Schluter $D$, Deckert $M$. The divergent role of tumor necrosis factor receptors in infectious diseases. Microbes Infect 2000;2:1285-92

35 Roach DR, Bean AGD, Demangel C, France MP, Briscoe H, Britton WJ. TNF regulates chemokine induction essential for cell recruitment, granuloma formation, and clearance of mycobacterial infection. J Immunol 2002;168:4620-7.

36 Bekker LG, Freeman S, Murray PJ, Ryffel B, Kaplan G. TNFalpha controls intracellular mycobacterial growth by both inducible nitric oxide synthasedependent and inducible nitric oxide synthase-independent pathways. $J$ Immunol 2001;166:6728-34.

37 Fisher CJ Jr, Agosti JM, Opal SM, Lowry SF, Balk RA, Sadoff JC, et al. Treatment of septic shock with the tumor necrosis factor receptor:Fc fusion protein. The Soluble TNF Receptor Sepsis Study Group. N Engl J Med 1996:334: 1697-702.

38 Herbein G, O'Brien WA. Tumor necrosis factor (TNF)-alpha and TNF receptors in viral pathogenesis. Proc Soc Exp Biol Med 2000;223:241-57.

39 Zhu N, Khoshnan A, Schneider R, Matsumoto M, Dennert G, Ware C, et al. Hepatitis $C$ virus core protein binds to the cytoplasmic domain of tumor necrosis factor (TNF) receptor 1 and enhances TNFinduced apoptosis. J Virol 1998;72:3691-7.

40 Walker RE, Spooner KM, Kelly G, McCloskey RV, Woody JN, Falloon J, et al. Inhibition of immunoreactive tumor necrosis factor-alpha by a chimeric antibody in patients infected with human immunodeficiency virus type 1. $J$ Infect Dis 1996;174:63-8.

41 Aboulafia DM, Bundow D, Wilske K, Ochs UI. Etanercept for the treatment of human immunodeficiency virus-associated psoriatic arthritis. Mayo Clin Proc 2000:75:1093-8. 